\title{
PATHOPHYSIOLOGY OF SEVERE DIARRHOEA AND SUGGESTED INTRAVENOUS FLUID THERAPY IN CALVES OF DIFFERENT AGES UNDER FIELD CONDITIONS
}

\author{
J. BOUDA ${ }^{1}$, J. DOUBEK ${ }^{2}$, M. MEDINA-CRUZ ${ }^{\vdots}$. L. PAASCH M. ${ }^{1}$, E. CANDANOSA A. ${ }^{1}$, \\ R. DVOŘÁK ${ }^{4}$ and V. SOŠKA ${ }^{5}$
}

${ }^{1}$ Department of Clinical Diagnosis, ${ }^{3}$ Department of Diseases and Production of Ruminants, College of Veterinary Medicine, National Autonomous Lniversity of Mexico, 04510 Mexico, D. F.,

${ }^{2}$ Department of Pathophysiology, ${ }^{4}$ Clinic of Ruminant Disease, Faculty of Veterinary Medicine, University of Veterinary and Pharmaceutical Sciences, 61242 , Brno, ${ }^{5}$ Department of Clinical Biochemistry, University Hospital. Masaryk University Brno

Received February 24, 1997

Accepted June 17, 1997

\begin{abstract}
Bouda J., J. Doubek. M. Medina-Cruz, L. Paasch M., E. Candanosa A., R. Dvořák, V. Sošk a: Pathophysiology of Severe Diarrhoea and Suggested Intravenous Fluid Therapy in Calves of Different Ages under Field Conditions. Acta vet. Brno 1997, 66: 87-94.
\end{abstract}

Selected clinical and biochemical variables were studied in 2 groups of severely dehydrated, diarrhoeic calves before and after fluid therapy. Group $1(n=10)$ included calves aged 2 to $7 \mathrm{~d}$, Group $2(n=9)$ calves aged 8 to $14 \mathrm{~d}$. Clinical examination and blood sampling for biochemical and haematological analyses were performed in each animal before and after fluid therapy. Samples of faeces for microbiological examination were taken before intravenous (IV) rehydration. Solutions used for IV rehydration contained salts of $\mathrm{NaCl}, \mathrm{NaHCO}_{3}, \mathrm{KCl}$ and glucose in different quantities for calves in Groups 1 and 2. These rehydration solutions were infused IV at a volume of $4 \mathrm{I}$ to each calf during 3 hours and then followed by oral rehydration. In Group 1, rotavirus in faeces was diagnosed in $50.0 \%$ of all calves; combined infectious agents rotavirus and Cryptosporidium spp. occurred in $10.0 \%$, none of the calves had in faeces coronavirus, enterotoxigenic $E$. coli $\mathrm{K} 99$ and Salmonella spp.; that means in $40 \%$ of calves of this group no infectious agents were isolated. In Group 2, coronavirus was found in $11.1 \%$, combined infectious agents rotavirus and Cryptosporidium spp. were diagnosed in $55.5 \%$. none of the calves had enterotoxigenic E. coli K99 or Salmonella spp in faeces.

Before IV rehydration diarrhoeic calves in Group 2 presented mean blood values of $\mathrm{pH}$ 7.12 , base excess (BE) $-14.72 \mathrm{mmol} / \mathrm{l}$, standard bicarbonate (SB) $9.86 \mathrm{mmol} / \mathrm{l}$ which were significantly lower $(\mathrm{P}<0.05)$ than in calves in Group 1 before IV rehydration, where $\mathrm{pH}$ was 7.16. $\mathrm{BE}-11.68 \mathrm{mmol} / \mathrm{l}$ and $\mathrm{SB} 12.54 \mathrm{mmol} / \mathrm{l}$. In both groups of calves before IV rehydration these low values of blood $\mathrm{pH}, \mathrm{BE}, \mathrm{SB}$ and normal value of $\mathrm{pCO}_{2}$, corresponded to partially compensated metabolic acidosis. The differences in blood values of $\mathrm{pH}, \mathrm{BE}, \mathrm{SB}, \mathrm{PCV}$, urea and $\mathrm{K}$ in both groups before and after rehydration were significant $(\mathrm{P}<0.01)$. The metabolic acidosis together with hyperkalemia, prerenal uremia and haemoconcentration were restored after fluid therapy. Rehydration was successful in $79.0 \%$ of all diarrhoeic calves. Calves aged $8 \mathrm{~d}$ or older suffering from severe diarrhoea needed more bicarbonate for IV rehydration than diarrhoeic calves younger than $8 \mathrm{~d}$. The suggested composition and volume of solutions for IV rehydration used in this study simplify fluid therapy in severely diarrhoeic calves of different ages in lateral or sternal recumbency without suckling reflex and under field conditions.

Neonatal diarrhoea, dehydration, metabolic acidosis, hyperkalemia, uremia, packed cell volume, fluid therapy, calf

Diarrhoea with dehydration is frequent in calves during the first 3 weeks of their life, and it is the most important cause of morbidity and mortality. The most commonly recognized causes of neonatal calf diarrhoea are rotavirus, coronavirus, 
Cryptosporidium spp., enterotoxigenic E. coli and nutritional abnormalities (Salajka and Ulmann 1972; Acres et al. 1977; Reynolds et al. 1986; Snodgras set al. 1986; B oud a et al. 1990). When solving the problem of neonatal death losses in dairy calves it is necessary to evaluate their colostral immunity (immunoglobulin status), and feeding, housing, management, disinfection, health status and vaccination programs in their dams (Medin a 1994; McGuirk 1996; Meltzer and Shpigel 1996).

In pathogenesis of diarrhoea the most important changes occur in the function of the intestinal mucosa. Diarrhoea is a result of either increased secretion or decreased absorption in the intestine. Bacteria such as enterotoxigenic E. coli, and to some extent Salmonella spp. cause neonatal diarrhoea by secreting enterotoxins, which stimulate increased intestinal secretions (Argenzio 1985; Bywater 1977; Fromm et al.1974). These changes are mediated by the cyclic adenosine monophosphate or cyclic guanosine 4,5-monophosphate, calmodulin and changes in protein kinase activity (Argenzio 1985). Cell structure is not affected, but the activity of membrane pumps is altered, and therefore, the secretion of sodium, chloride and potassium is increased (B y w at er and Log an 1974).

Enteric viruses (rotavirus, coronavirus) and protozoa (Cryptosporidium spp.) cause neonatal diarrhoea as a result of destruction of the absorptive villous epithelial cells. Diarrhoea due to rotavirus and coronavirus follows because intestinal secretion continues, while absorption is impaired (M e b u s et al. 1973; Mo on 1978; W o ode et al. 1978). The osmotic effect of unabsorbed nutrients drains water into the gut and further aggravates diarrhoea (A cres 1985). Inflammation of the intestinal mucosa is a sign of salmonellosis and clostridiosis, which contributes to diarrhoea by increasing mucosa pore size and hydraulic pressure in the intestinal wall by destroying the absorptive cells and by increasing prostaglandin production, which stimulates mucosal secretory mechanisms (A rg e n zio 1985).

Metabolic changes associated with neonatal diarrhoea in calves have been studied extensively. Major disturbances in diarrhoeic calves are dehydration, metabolic acidosis, electrolyte abnormalities and uremia. Fluid is lost preferentially from the vascular space ( $\mathrm{N}$ a y lor 1987; B ou da et al.1994).

The objective of this work was to study the pathophysiology of severe diarrhoea in calves from 2 to $7 \mathrm{~d}$ old and calves between 8 to $14 \mathrm{~d}$ old, and their response to intravenous (IV) fluid therapy.

\section{Materials and Methods}

We used 19 Holstein-Friesian calves aged 2 to $14 \mathrm{~d}$ suffering from profuse diarrhoea and severe dehydration. They were located in 2 farms: one farm had a capacity of 420 and the second of 600 dairy cows. All dry cows were vaccinated against $E$. coli $K 99$. After birth calves were separated from their dams and placed indoors in individual calf boxes. They were offered by bottle 21 of colostrum from their mothers twice a day during the first $4 \mathrm{~d}$ of life, and thereafter they were fed milk or commercial milk replacer. The calves were divided into 2 groups by age. In Group $1(n=10)$ calves were 2 - to 7-d-old, in Group $2(n=9)$ calves 8- to 14-d-old. The calves were weighed at birth, three times a week, and before and after IV rehydration. The mean body mass of calves at birth in Group 1 was $38.2 \mathrm{~kg}$ ( 36.2 to 41.1) and in Group 2 it was $39.3 \mathrm{~kg}$ ( 37.4 to 43.7 ). At clinical examination we registered: respiratory and cardiac frequencies, body temperature, behaviour, presence or absence of suckling reflex, severity of diarrhoea, severity of dehydration (sunken eyes, elasticity of the skin, colour and humidity of mucosas) and physical status (standing, sternal or lateral recumbency). There was profuse diarrhoea, severe dehydration and absence of suckling reflex in both groups in either sternal or lateral recumbency in all animals studied.

Blood samples for biochemical and haematological analyses were collected from the jugular vein before IV rehydration and 48 hours thereafter. Indicators of acid-base status $(\mathrm{pH}$, partial pressure of carbon 
dioxide-pCO, base excess-BE, standard bicarbonate-SB) were determined by means of the Acid-base analyzer-ABL 3, Radiometer (Copenhagen) in heparinized blood samples, within $3 \mathrm{~h}$ of collection. In several animals, analyses were done 4 to $12 \mathrm{~h}$ after the collection of the samples. Therefore, correcting factors were used for acid-base results (J a g o š et al. 1977). Packed cell volume (PCV) was determined by microhaematocrit methods. The following indicators were determined in blood plasma: urea and glucose by the Analyzer Micro-chem 565 (Ciba Corning) Na and $\mathrm{K}$ were determined by atomic absorption spectrophotometry (Perkin-Elmer 3110). All samples of faeces for microbiology examination, (enterotoxigenic E. coli K99, Salmonella spp., rotavirus, coronavirus and Cryptosporidium spp.) were taken before rehydration.

For IV rehydration we used isotonic sterile solutions with salts of $\mathrm{NaCl}, \mathrm{NaHCO}, \mathrm{KCl}$ and slightly hypertonic solution of glucose. The composition of the solutions for IV rehydration was based on preliminary experimental results using 10 diarrhoeic calves. The composition of the infused solutions for Group 1 was as follows: $18 \mathrm{~g}$ of $\mathrm{NaCl}(2 \mathrm{l}$ of $0.9 \% \mathrm{NaCl}), 17 \mathrm{~g}$ of $\mathrm{NaHCO}_{3}\left(1.3 \mathrm{l}\right.$ of $\left.1.3 \% \mathrm{NaHCO}_{3}\right)$, and slightly hypertonic solution of $50 \mathrm{~g}$ of glucose $(0.5 \mathrm{l}$ of $10 \%$ glucose $), 2.2 \mathrm{~g}$ of $\mathrm{KCl}(200 \mathrm{ml}$ of $1.1 \% \mathrm{KCl})$ making a total volume of $4.0 \mathrm{l}$. The composition and volume of the infused solution for Group 2 was: 13.5 $\mathrm{g}$ of $\mathrm{NaCl}(1.5 \mathrm{l}$ of $0.9 \% \mathrm{NaCl}), 23.4 \mathrm{~g}$ of $\mathrm{NaHCO}_{3}\left(1.8 \mathrm{l}\right.$ of $\left.1.3 \% \mathrm{NaHCO}_{3}\right), 50 \mathrm{~g}$ of glucose $(0.5 \mathrm{l}$ of $10 \%$ glucose), $2.2 \mathrm{~g}$ of $\mathrm{KCl}(200 \mathrm{ml}$ of $1.1 \% \mathrm{KCl})$, making a total of $4.0 \mathrm{l}$.

The first liter of warmed IV rehydration solution was infused within 30 minutes using IV plastic catheters, and the remaining $3.0 \mathrm{l}$ were infused within approximately 2.5 hours.

The IV rehydration was followed by oral rehydration which consisted of $4.2 \mathrm{~g}$ of $\mathrm{NaCl}, 4.0 \mathrm{~g}$ of $\mathrm{NaHCO}_{3}$, $1.6 \mathrm{~g}$ of $\mathrm{KCl}$ and $20 \mathrm{~g}$ of glucose dissolved in 11 water. The total volume of oral fluids per calf/day was $6 \mathrm{I}$ divided in 3 equal doses.

Milk or milk replacer was witheld from the diet of calves for a period of 36 to $48 \mathrm{~h}$. The treatment of dehydrated diarrhoeic calves in addition to IV and oral rehydration, included oral antibiotic therapy for 3 days ( 2 calves in Group 1 and 1 calf in Group 2) and symptomatic therapy consisting of warming of the body using bags with luke-warm water or infrared lamps.

Results were statistically analysed by the Student 's t- test and analysis of variance, and were expressed as means $+\mathrm{SD}$.

\section{Results}

Calves from both groups were severely dehydrated and showed no suckling reflex. In Group 1, 5 calves were in sternal and 5 in lateral recumbency. In Group 2, 6 calves were in sternal and 3 in lateral recumbency. Clinical signs of dehydration, especially enophtalmus were more severe in calves of Group 1. Body mass losses made the difference between the last weighing and the weighing before the moment of rehydration. The loss of body mass for Group 1 of calves was $9.76 \%(8.1-10.5 \%)$, and for Group 2, $9.32 \%(8-10.2 \%)$. Body temperature in Group 1 was normal in 4 calves and decreased in 6 calves; in Group 2 it was normal in 5 and decreased in 4 calves.

In Group 1, rotavirus in faeces was diagnosed in $50.0 \%$ of all calves; combined infectious agents rotavirus and Cryptosporidium spp. occurred in $10.0 \%$, none of the calves had coronavirus, enterotoxigenic E. coli $\mathrm{K} 99$ and Salmonella spp. in faeces. In $40.0 \%$ of calves no infectious agents were isolated in faeces. In Group 2, coronavirus was found in $11.1 \%$, combined infectious agents rotavirus and Cryptosporidium spp. were diagnosed in $55.5 \%$ and none of the calves had enterotoxigenic $E$. coli $\mathrm{K} 99$ or Salmonella spp. in faeces. In $33.4 \%$ of calves, no infectious agents were isolated from faeces.

The most important pathophysiological changes in all calves of both groups before IV rehydration were profuse diarrhoea, severe dehydration, very low blood $\mathrm{pH}, \mathrm{BE}$, $\mathrm{SB}$ and increased PCV, plasma urea and $\mathrm{K}$ concentrations. The biochemical indices in heparinized blood and plasma of calves before and after IV rehydration are presented in Tables 1 and 2 .

The decrease in $\mathrm{pH}, \mathrm{BE}$ and $\mathrm{SB}$ before IV rehydration was more evident in calves of Group 2 than in calves of Group 1, and this difference was significant $(\mathrm{P}<0.05)$. 
Table 1

Values of acid-base status and PCV in calves before IV rehydration

\begin{tabular}{|c|c|c|c|c|c|}
\hline \multicolumn{6}{|c|}{ Before IV rehydration } \\
\hline $\begin{array}{c}\text { Group of } \\
\text { calves }\end{array}$ & $\mathrm{pH}$ & $\begin{array}{c}\mathrm{BE}^{*} \\
\mathrm{mmol} / \mathrm{l}\end{array}$ & $\begin{array}{c}\mathrm{SB}^{*} \\
\mathrm{mmol} / 1\end{array}$ & $\begin{array}{c}\mathrm{pCO}_{2}{ }^{*} \\
\mathrm{KPa}^{2}\end{array}$ & $\begin{array}{c}\mathrm{PCV}^{*} \\
(\mathrm{I} / \mathrm{I})\end{array}$ \\
\hline $1(\mathrm{n}=10)$ & $\begin{array}{l}7.161 \\
0.053\end{array}$ & $\begin{array}{r}-11.68 \\
2.75\end{array}$ & $\begin{array}{r}12.54 \\
2.67\end{array}$ & $\begin{array}{l}5.21 \\
0.55\end{array}$ & $\begin{array}{l}0.44 \\
0.07\end{array}$ \\
\hline $2(n=9)$ & $\begin{aligned} 7.123 \\
0.061 \\
\mathrm{P}<0.05\end{aligned}$ & $\begin{array}{r}-14.72 \\
3.43 \\
P<0.05\end{array}$ & $\begin{array}{r}9.86 \\
3.22 \\
P<0.05\end{array}$ & $\begin{array}{r}5.43 \\
0.67 \\
\text { N. S. }\end{array}$ & $\begin{array}{l}0.42 \\
0.06 \\
\text { N. S. }\end{array}$ \\
\hline \multicolumn{6}{|c|}{ After IV rehydration (48 hours) } \\
\hline $1(n=8)$ & $\begin{array}{l}7.357 \\
0.04\end{array}$ & $\begin{array}{l}2.17 \\
2.98\end{array}$ & $\begin{array}{r}25.89 \\
2.87\end{array}$ & $\begin{array}{l}5.77 \\
0.65\end{array}$ & $\begin{array}{l}0.32 \\
0.05\end{array}$ \\
\hline $2(n=7)$ & $\begin{array}{l}7.348 \\
0.053 \\
\text { N.S. }\end{array}$ & $\begin{array}{r}1.35 \\
2.93 \\
\text { N.S. }\end{array}$ & $\begin{array}{r}25.13 \\
2.74 \\
\text { N.S. }\end{array}$ & $\begin{array}{c}5.55 \\
0.69 \\
\text { N. S. }\end{array}$ & $\begin{array}{c}0.33 \\
0.06 \\
\text { N.S. }\end{array}$ \\
\hline
\end{tabular}

$* \mathrm{BE}=$ base excess. $\mathrm{SB}=$ standard bicarbonate, $\mathrm{pCO}_{2}=$ partial tension of $\mathrm{CO}_{2}, \mathrm{PCV}=$ packed cell volume .

Table 2

Biochemical values in blood plasma of calves before and after IV rehydration

\begin{tabular}{|ccccc|}
\hline \multicolumn{5}{c|}{ Before IV rehydration } \\
\hline $\begin{array}{c}\text { Group of } \\
\text { calves }\end{array}$ & $\begin{array}{c}\text { Urea } \\
\mathrm{mmol} / 1\end{array}$ & $\begin{array}{c}\text { Glucose } \\
\mathrm{mmol} / \mathrm{l}\end{array}$ & $\begin{array}{c}\mathrm{Na} \\
\mathrm{mmol} / 1\end{array}$ & $\mathrm{~K}$ \\
\hline $1(\mathrm{n}=10)$ & 13.8 & 5.12 & 134.4 & $\mathrm{mmol} / 1$ \\
& 5.1 & 1.60 & 7.2 & 5.72 \\
$2(\mathrm{n}=9)$ & 14.2 & 4.48 & 137.3 & 1.01 \\
& 5.32 & 1.45 & 8.6 & 5.81 \\
& N.S. & N.S. & N.S. & N.S. \\
\hline & & After IV rehydration $(48$ hours $)$ & & \\
\hline $1(\mathrm{n}=8)$ & 5.3 & 5.03 & 139.6 & 4.94 \\
& 1.7 & 1.2 & 6.3 & 0.77 \\
$2(\mathrm{n}=7)$ & 5.7 & 4.87 & 142.5 & 5.07 \\
& 1.9 & 1.3 & 7.3 & 0.58 \\
& N.S. & N.S. & N.S. \\
\hline
\end{tabular}

Values of $\mathrm{pCO}_{2}, \mathrm{PCV}$, urea, glucose, $\mathrm{Na}$ and $\mathrm{K}$ in both groups of diarrhoeic calves before rehydration were not different. Severe metabolic acidosis (partially compensated), hyperkalemia, prerenal uremia and hemoconcentration were observed in diarrhoeic calves before IV rehydration. The differences in blood values of $\mathrm{pH}, \mathrm{BE}, \mathrm{SB}, \mathrm{PCV}$, urea and $\mathrm{K}$ in both groups of calves before and after rehydration were significant $(\mathrm{P}<0.01)$. After IV and oral rehydration, biochemical values in blood were restored and there were no significant differences in these variables between Groups 1 and 2. The IV rehydration combined with oral 
rehydration was successful in 15 out of 19 calves $(79.0 \%)$. The therapy efficiency was estimated on the base of clinical examination of the animals and comparison of biochemical values in blood before and after rehydration. The causes of death in 2 calves of Group 1 and in 2 calves of Group 2 were severe metabolic acidosis, dehydration and uremia.

\section{Discussion}

Diarrhoea associated with dehydration, metabolic acidosis and electrolyte abnormalities are the main health problems in calves up to 3 weeks of age. From this study, it is evident that the important etiologic agents causing diarrhoea in calves aged 2 to $14 \mathrm{~d}$ are: rotavirus, Cryptosporidium spp. and coronavirus. Similar findings were described by Reynolds et al. (1986) and Snodgrass et al. (1986). Negative microbiological findings were obtained in $36.8 \%$ of all diarrhoeic calves. Other possible causes of diarrhoea are non-infectious such as feeding high volumes of milk at once, low quality milk replacers, feeding cold milk, calving or rearing in droughty or humid housing conditions.

Dehydration in diarrhoeic calves results from faecal fluid loss and decreased fluid intake due to anorexia or withdrawal of milk. Faecal volume in diarrhoeic calves can reach as much as $13 \%$ of their body mass in $24 \mathrm{~h}$ as compared to $0.3 \%$ in non-diarrhoeic calves (Lew is and Phillips 1972). In our study the degree of dehydration and changed PCV were more evident in diarrhoeic calves under 7 d of age than in older calves; these findings correspond to those of $\mathrm{N}$ a y lor (1987, 1996), Roussel and Kasari (1990). According to Roussel and Kasari (1990) the experienced veterinarian can classify dehydrated calves by assessing clinical signs such as enophtalmus, decreased skin elasticity, lack of suckling reflex, posture and surface temperature of the extremities. These dehydrated calves can be classified in two groups: 1) animals requiring intravenous rehydration therapy and 2) animals that will respond to oral rehydration. Intravenous rehydration is indicated in calves suffering from over $8 \%$ dehydration (Michel et al. 1989; Radostits et al. 1994; Medina 1994). Values of PCV were significantly increased in diarrhoeic calves before IV rehydration, as compared with those after rehydration. This agrees with the reference values stated by B ouda and J a goš (1984).

Metabolic acidosis is a consistent complication of diarrhoea caused by bicarbonate loss in the diarrhoeic faeces, by lactic acid accumulation in poorly perfused tissues, by reduced acid excretion in poorly perfused kidneys and by organic acid production in the colon as a result of fermentation of unabsorbed nutrients (Roussel and Kasari 1990; B ouda and Jagoš 1991; Medina 1994).

A fast technique to estimate the degree of metabolic acidosis is to use acid-base analyzers if they are available. The determination of base excess in blood is especially important for the treatment of metabolic acidosis. Bicarbonate requirements for neutralizing acidosis in calves can be calculated from the Mellemgaard-Astrup equation as follows:

Bicarbonate requirements $(\mathrm{mmol})=\mathrm{BE}(\mathrm{mmol} / \mathrm{l}) \times 0.5 \times$ body mass $(\mathrm{kg})$.

One g of $\mathrm{NaHCO}_{3}$ equals to $12 \mathrm{mmol}$ of bicarbonate or $1.0 \mathrm{ml}$ of a $8.4 \%$ solution of $\mathrm{NaHCO}_{3}$ equals to one mmol of bicarbonate (Kas a r i 1990; B ou da et al. 1994, $\mathrm{R}$ adostits et al.1994;). The estimation of the acid-base status in diarrhoeic calves 
over $7 \mathrm{~d}$ old on the basis of clinical signs of dehydration, is less reliable than in calves younger than $7 \mathrm{~d}$ (Naylor 1996). From our results, it is evident that the severely dehydrated calves over 1 week of age presented more severe metabolic acidosis $(\mathrm{BE}=-14.72 \mathrm{mmol} / \mathrm{l})$ than the younger ones (under 7 days old, $\mathrm{BE}=-11.68 \mathrm{mmol} / \mathrm{l})$. Very similar results are described by N aylor $(1987,1996)$. Diarrhoeic calves younger than $7 \mathrm{~d}$ in sternal or lateral recumbency, suffering from severe dehydration and showing no suckling reflex, with determined $\mathrm{BE}=-11.68 \mathrm{mmol} / \mathrm{l}$, will need 209 mmol of $\mathrm{NaHCO}_{3}\left(17.4 \mathrm{~g}\right.$ of $\left.\mathrm{NaHCO}_{3}\right)$ or $1.3 \mathrm{l}$ of a $1.3 \%$ solution of $\mathrm{NaHCO}_{3}$. On the other hand, calves over $7 \mathrm{~d}$ of age with $\mathrm{BE}=-14.72 \mathrm{mmol} / \mathrm{l}$ need to neutralize the metabolic acidosis, $279 \mathrm{mmol}$ of $\mathrm{NaHCO}_{3}\left(23.5 \mathrm{~g}\right.$ of $\mathrm{NaHCO}_{3}$ or $1.8 \mathrm{l}$ of a $1.3 \%$ solution of $\mathrm{NaHCO}_{3}$.

Concentrations of plasma electrolytes provide the assessment of their content in the extracellular compartment but they do not offer good information on the total electrolyte content in the body of the animal (B ouda et al. 1990; R oussel and Kasari 1990). Before IV rehydration there was hyperkalemia in both groups of diarrhoeic calves as compared with the values after IV rehydration or the reference values stated by Bouda and Jagoš (1984). Hyperkalemia occurs in severely diarrhoeic calves, because $\mathrm{H}$ ions diffuse from acid plasma into the intracellular fluid compartment and in order to maintain electroneutrality, $\mathrm{K}$ ions diffuse into the plasma. Actually, the total body $\mathrm{K}$ content is decreased, because it is lost through the diarrhoeic faeces and the renal excretion. Therefore, salts of $\mathrm{KCl}$ were added to the IV rehydration solution. The quantity of added $\mathrm{KCl}$ in our IV solutions was lower than that in solutions recommended by Roussel and Kas a ri (1990). In spite of the addition of salts of $\mathrm{KCl}$ to the IV rehydration solutions for hyperkalemic diarrhoeic calves, plasma levels after IV rehydration were restored. In our opinion it is convenient to add $\mathrm{KCl}$ to IV rehydration solutions in the dose as we have done. Plasma concentrations of sodium in calves before and after IV rehydration were in the range of reference values determined by B ouda and $\mathrm{J}$ a goš (1984) but the total body content of sodium was reduced in diarrhoeic calves due to severe dehydration. In dehydrated diarrhoeic calves, it is important to replace the extracellular volume with solutions containing $\mathrm{Na}$ ions at the same concentrations as in the blood plasma. Plasma glucose concentrations below the reference values (B ouda and Jagoš 1984) were only found in diarrhoeic calves over $7 \mathrm{~d}$ of age. According to R oussel and K as a r i (1990), the addition of glucose to rehydration solutions includes these benefits: glucose is the source of energy especially for hypothermic, hypoglycemic calves, and it also stimulates the release of insulin which in turn enhances the movement of $\mathrm{K}$ from the extracellular compartment to the intracellular compartment.

The success of the treatment of diarrhoea depends on the etiologic agents, clinical signs of diarrhoea, degree of dehydration, age of the calves, composition and doses of rehydrating solutions including the antibiotic and symptomatic therapy (B o u d a et al. 1994; Radostits et al. 1994). The infectious agents, antibiotic and symptomatic therapy in both groups of calves were in our study practically similar, therefore we assume that the main cause of the severe metabolic acidosis in Group 2 was the age of animals and these findings are in agreement with the results obtained by $\mathrm{N}$ a y l or $(1987,1996)$. The suggested composition and volume of solutions for IV fluid therapy used in this study simplify the fluid therapy in calves of different ages (up to $7 \mathrm{~d}$ and over $7 \mathrm{~d}$ old) with severe diarrhoea, showing no suckling reflex and in recumbency under field conditions. 


\section{Patofyziologie těžkých průjmů a navržená intravenózní rehydratace u telat různého věku v podmínkách praxe}

Vybrané klinicko-biochemické ukazatele byly studovány u 2 skupin telat s těžkými průjmy před a po rehydratační léčbě. $\mathrm{V} 1$. skupině $(\mathrm{n}=10)$ byla telata ve věku 2 až 7 dní, ve 2. skupině $(n=9) 8$ až 14 dní. Klinické vyšetření a odběr krevních vzorků pro biochemické a hematologické vyšetření bylo provedeno u všech zvírat před intravenózní (i.v.) a po rehydratační léčbě. Mikrobiologické vyšetření vzorků trusu bylo provedeno před i.v. rehydratací. Použité roztoky pro i.v. rehydrataci obsahovaly soli $\mathrm{NaCl}$, $\mathrm{NaHCO}_{3}, \mathrm{KCl}$ a glukózu v rozdílných dávkách pro telata 1. a 2. skupiny. Tyto roztoky v objemu $4 \mathrm{l}$ byly aplikovány i.v. během 3 h s následnou perorální rehydratací. V trusu 1 . skupiny byl zjištěn rotavirus u $50,0 \%$ zvírat; rotavirus a Cryptosporidium spp. byly současně nalezeny u 10,0 \%, koronavirus, enterotoxigenní E. coli K99 a Salmonella spp. nebyly nalezeny u žádného telete, což znamená, že u 40,0 \% telat této skupiny nebyly v trusu zjištěny infekční agens. V2. skupině telat byl koronavirus v trusu zjištěn u $11,1 \%$, rotavirus a Cryptosporidium spp. byly současně diagnostikovány u 55,5\%; u žádného telete této skupiny nebyly v trusu zjištěny enterotoxigenní E.coli K99 a Salmonella spp.

U průjmujících telat 2 . skupiny byly před i.v. rehydratací průměrné hodnoty $\mathrm{pH}$ krve 7,123, base excess (BE) -14,72 mmol/l, standardního bikarbonátu (SB) 9,86 $\mathrm{mmol} / \mathrm{l}$ významně nižší $(\mathrm{P}<0,05)$ než u průjmujících telat 1 . skupiny pred i.v. rehydratací, $\mathrm{kde} \mathrm{pH}$ krve bylo 7,161, BE -11,68 mmol/1, SB 12,54 mmol/l. Velmi nízké hodnoty $\mathrm{pH}$ krve, $\mathrm{BE}, \mathrm{SB}$ a normální hodnota $\mathrm{pCO}_{2}$ krve svědčí pro částečně kompenzovanou metabolickou acidózu. $\mathrm{V}$ hodnotách $\mathrm{pH}, \mathrm{BE}, \mathrm{SB}$, hematokritu, močoviny a $\mathrm{K}$ byly u obou skupin telat před rehydratací a po rehydrataci signifikantní rozdíly $(\mathrm{P}<0.01)$. Metabolická acidóza doprovázena hyperkalémií, prerenální urémií a hemokoncentrací byly normalizovány použitou rehydratační léčbou, která byla úspěšná v $79.0 \%$ všech telat s těžkým průjmem. Taková telata ve věku nad 7 dní potřebují při i.v. rehydrataci více $\mathrm{NaHCO}_{3}$ než telata s těžkým průjmem mladší než 7 dní. Složení a objem rehydratačních roztoků pro i.v. aplikaci, použité v této studii, výrazně přispívají ke zjednodušení i.v. rehydratační terapie u telat s těžkým průjmem bez sacího reflexu, bez schopnosti povstat, zejména $\mathrm{v}$ podmínkách praxe.

\section{References}

ACRES, S. D. 1985: Enterotoxigenic Escherichia coli infection in newborn calves. J. Dairy Sci. 68:229-256 ACRES, S. D., SAUNDERS, J., RADOSTITS, O.,M. 1977: Acute undifferentiated neonatal diarrhea of beef calves: the prevalence of enterotoxigenic E. coli, reo-like (rota) virus and other enteropathogens in cow-calf herds. Can. vet. J. 18:113-121

ARGENZIO, R. A. 1985: Pathophysiology of neonatal calf diarrhea. Vet. Clin. North Am. (Food Anim. Pract). 1:461-469

BOUDA, J., DOUBEK, J., TOTH, J., KLIMES, J., HRUŠKOVÁ. M. 1990: Príspěvek k etiopatogenezi a léčbě průjmových onemocnění telat. Veterinářství 40:292-294

BOUDA, J., DOUBEK, J., TOTH, J. 1994: Průjmová onemocnění telat. Nové poznatky v rehydratační léčbě. Veterinářství 44:103-106

BOUDA, J., JAGOS, P. 1984: Biochemical and hematological reference values in calves and their significance for health control. Acta vet. Brno 53:137-142

BOUDA, J., JAGOS, P. 1991: Disorders in the acid-base balance. In Vrzgula L: Metabolic disorders and their prevention in farm animals. Elsevier, Amsterdam, pp. 248-268

BYWATER, R. J. 1977: Evaluation of an oral glucose-glycine-electrolyte formulation and amoxicillin for treatment of diarrhea in calves. Am. J. Vet. Res. 38:1983-1987

BYWATER, R. J., LOGAN, E. F. 1974: The site and characteristics of intestinal water and electrolyte loss in Escherichia coli-induced diarrhoea in calves. J. Comp. Pathol. 84:599-610 
FROMM, D., GIANELLA, R. A. FORMAL, S. B. 1974: Ion transport across isolated ileal mucosa invaded by Salmonella. Gastroenterology 66:215-225

JAGOŠ, P., BOUDA, J., PŘIKR YLOVÁ, J. 1977: Dynamika acidobazických změn venózní krve skotu in vitro v závislosti na čase. Vet. Med. (Praha) 22:257-260

KASARI, T. R. 1990: Metabolic acidosis in diarrheic calves: The importance of alkalinizing agents in therapy. Vet. Clin. North Am. (Food Anim Pract.) 6:29-43

LEWIS, L. D., PHILLIPS, R. W. 1972: Water and electrolyte losses in neonatal calves with acute diarrhea. a complete balance study. Cornell Vet. 62:596-607

MEBUS, C. A., STAIR, E. L., RHODES, M. B. 1973: Pathology of neonatal calf diarrhea induced by a coronavirus-like agent. Vet. Pathol. 10:45-64

McGUIRK, S. M. 1996: Neonatal calf management: A guide to disease investigation. Proceedings of the XIXth World Buiatrics Congress. Edinburgh, pp. 89-92.

MEDINA, C. M. 1994: Medicina productiva en la crianza de becerras lecheras. Limusa. D.F., México. $325 \mathrm{p}$.

MELTZER, R., SHPIGEL, N. Y. 1996: Etiologic and epidemiologic aspects of calf diarrhoea in Israeli dairy farms. Proceedings of the XIXth World Buiatrics Congress. Edinburgh, pp. 93-97.

MICHELL, A. R., BYWATER, R. J., CLARKE, K. W., HALL, L. W., WATERMAN, A. E. 1989: Veterinary fluid therapy. Blackwell Scientific Publications, Oxford, 312 p.

MOON, H. W. 1978: Mechanisms in the pathogenesis of diarrhea: a review. J. Am. Vet. Med. Assoc. 172:443-448

NAYLOR, J. M. 1987: Severity and nature of acidosis in diarrheic calves over and under one week of age. Can. vet. J. 28:168-173

NAYLOR, J. M. 1996: Neonatal ruminant diarrhea. In: Smith B. P.: Large Animal Internal Medicine, Mosby, St. Louis, pp. 396-417

RADOSTITS, O. M., BLOOD, D. C., GAY, C. C. 1994.: Veterinary Medicine. A textbook of the diseases of cattle, sheep, pigs, goats and horses. 8th edition, Baillière Tindall, London.

REYNOLDS, D. J., MORGAN, J. H. CHANTER N. 1986: Microbiology of calf diarrhoea in Southern Britain. Vet. Rec. 119:34-39

ROUSSEL, A. J., KASARI, T. R. 1990: Using fluid and electrolyte replacement therapy to help diarrheic calves. Vet. Med. 85:303-311

SALAJKA, E., ULMANN, L.: Prospects of specific prevention and treatment of diarrhoeic E. coli infections in calves in the early postnatal period. Acta vet. Brno (Suppl. 2), 40:83-86

SNODGRASS, D. R., TERZOLO, H. R. SHERWOOD, D. 1986: Aetiology of diarrhoea in young calves. Vet. Rec. 119: 31-34

WOODE, G. N., SMITH, C., DENNIS, M. J. 1978: Intestinal damage in rotavirus infected calves assessed by D-xylose malabsorption. Vet. Rec. 102:340-341 